\section{Yavuz Kayaş, Serhat Uysal*, Anıl Murat Öztürk**, Ilgın Yıldırım Şimşir***, Meltem Işıkgöz Taşbakan*, ilgen Ertam, Bilgin Arda*}

\begin{abstract}
Ege Üniversitesi Tıp Fakültesi,
\end{abstract} Dermatoloji Anabilim Dalı, İzmir, Türkiye

*Ege Üniversitesi Tıp Fakültesi, Enfeksiyon Hastalıkları ve Klinik Mikrobiyoloji Anabilim Dalı, İzmir, Türkiye

**Ege Üniversitesi Tıp Fakültesi, Ortopedi ve Travmatoloji Anabilim Dalı, İzmir, Türkiye

***Ege Üniversitesi Tıp Fakültesi, İç Hastalıkları Endokrinoloji ve Metabolizma Anabilim Dalı, İzmir, Türkiye

Yazışma Adresi/ Correspondence: Yavuz Kayaş, Ege Üniversitesi Tıp Fakültesi, Dermatoloji Anabilim Dall, İzmir, Türkiye

E-posta: dryavuzkayas@hotmail.com Geliş Tarihi/Submitted: 29.07.2013 Kabul Tarihi/Accepted: 30.07.2013

22-26 Mayıs 2013 tarihlerinde Antalya'da gerçekleşen 28. Ankem Antibiyotik ve Kemoterapi Kongresi'nde sunulmuştur.

@Telif Hakkı 2014 Türk Dermatoloji Derneği Makale metnine www. turkdermatolojidergisi.com web sayfasından ulaşılabilir.

@Copyright 2014 by Turkish Society of Dermatology - Available on-line at www.turkdermatolojidergisi.com

\title{
Diyabetik Ayak Enfeksiyonunda Nadir Rastlanilan Bir Etken: Achromobacter Xylosoxidans
}

\author{
A Rarely Seen, Causative of the Diabetic Foot \\ Infections: Achromobacter Xylosoxidans
}

\section{Özet}

Diyabetik hastalarda, ayak enfeksiyonları hastanede yatışı gerektiren en yaygın enfeksiyöz komplikasyonlar arasındadır. Achromobacter xylosoxidans, özellikle malinite, solid organ transplantasyonu, hipogamaglobulinemi, AIDS ve prematüre bebekler gibi immün sistemi baskılanmış hastalarda invaziv enfeksiyonlara yol açar. Bu yazıda diyabetik ayak enfeksiyonu etkeni olarak Achromobacter xylosoxidans saptanan iki olgu, nadir görülmesi nedeniyle sunulmuştur. Olgular 10 yıldan daha uzun süreli diyabeti olan ve diyabetik ayak komplikasyonu ile izlenen hastalardır. Yumuşak doku enfeksiyonu bulguları ile başvuran iki olgunun doku kültürlerinde Achromobacterxylosoxidans üremesi saptanmış, cerrahi debridman ve uygun antimikrobiyal tedavi ile klinik ve mikrobiyolojik yanıt alınmıştır. Diyabetik ayak enfeksiyonunun mikrobiyolojik tanısında doku kültürü yapılması gerçek etkeni saptamak açısından çok önemlidir. Mikrobiyolojik örneklemin doğru yapılması bizim olgularımızda olduğu gibi nadir görülen etkenlerin saptanması ve tedavisi açısından yol göstericidir.

Anahtar kelimeler: Diyabetik ayak enfeksiyonu, Achromobacter xylosoxidans

\section{Abstract}

Foot infections are the most common infectious complications needs patient to be hospitalized in persons with diabetes. Achromobacter xylosoxidans especially causes invasive infections in immunocompromised patients such as malignancy, solid organ transplantation, hypogammaglobulinemia, AIDS and premature babies. With this case report we want to present two cases of Achromobacter xylosoxidans as extremely rare seen cause of diabetic foot infection. The cases are followed up more than 10 years in our out-patient clinic with a diabetes and diabetic foot complications. The tissue cultures of these cases with the soft tissue infection were identified as Achromobacter xylosoxidans and with surgical debridement and antimicrobial therapy we get effective clinical and microbiological results. Tissue culture is very important to find and identify the real microorganism causing an infection in a diabetic foot infections. To make a true microbiological culture leads us to identify the extremely rare seen microorganisms and to plan the therapy as in our cases.

Key Words: Diabetic foot infections, Achromobacter xylosoxidans

\section{Giriş}

DünyaSağlıkÖrgütütarafından diyabetikayak; diyabetli hastada gelişen, alt ekstremitelerde nörolojik bozukluklar, çeşitli derecelerde periferik vasküler hastalık ve/veya metabolik komplikasyonlarla ilişkili olarak enfeksiyon, ülserasyon ve derin dokularda destrüksiyonu içeren patolojik potansiyel sonuçları olan durumlar olarak tanımlanmıştır (1).
Diyabetik hastaların yaklaşık \%25'inde yaşamları boyunca ayaklarında yara açılması olasılığı bulunduğu ve ayak infeksiyonlarının hastanede yatışı gerektiren en yaygın enfeksiyöz komplikasyonlar arasında olduğu bildirilmektedir (2).

Diyabetik ayak enfeksiyonları, polimikrobiyal enfeksiyonlardır. Staphylococcus aureus ve beta-hemolitik streptokoklar ilk kez gelişen enfeksiyonlarda en sık karşılaşılan 
etkenler olmakla birlikte tekrarlayan enfeksiyonlarda, daha önce hastaneye yatış öyküsü olan ve önceden antibiyotik kullananlarda enterokoklar, Escherichia coli, Klebsiella spp., Proteus spp., Bacteroides fragilis, peptostreptokoklar, Pseudomonas aeruginosa ve Acinetobacter türleri de etken olabilmektedir (3).

Achromobacter xylosoxidans, aerop, nonfermentatif, insanlarda nadiren infeksiyona neden olan gram negatif bir bakteridir. Özellikle malinite, solid organ transplantasyonu, hipogamaglobulinemi, AIDS ve prematüre bebekler gibi immün sistemi baskılanmış hastalarda invaziv enfeksiyonlara yol açar (4). Bu yazıda diyabetik ayak enfeksiyonu etkeni olarak Achromobacter xylosoxidans saptanan iki olgu, nadir görülmesi nedeniyle sunulmuştur.

\section{Olgu Sunumları}

\section{Olgu 1}

On yıldır diyabeti olan 80 yaşındaki erkek hastaya, yaklaşık bir ay önce ayak ve bacakta ağrı, ayak parmaklarında kızarıklık, ısı artışı ve morarma şikayetleri nedeniyle gittiği doktorlar tarafından çeşitli tedaviler uygulanmıştır. Yakınmalarının geçmemesi nedeniyle hastanemiz diyabetik ayak konseyine başvuran hastanın muayenesinde diyabetik ayak enfeksiyonu Wagner 4, Pedis 3 olarak değerlendirilmiştir. Doku kültürü alınarak Dermatoloji Kliniği'ne yatırılmıştır. Hastanın öyküsünden kan şekeri regülasyonunun düzenli olmadığı, son bir yıldır ayak parmaklarında ve ayağında yaralar oluştuğu, topikal ve sistemik antibiyotik tedavi aldığı öğrenildi. Hastanın fizik muayenesinde sol ayak alt tibial bölge anteriorunda $4 \times 3 \mathrm{~cm}$ çapında yüzeyel ülserasyon, sağ ayaküçüncü parmak uç kısımda nekrotik enfekte görünüm, sol ayak birinci parmak uç kısmında nekrotik kurutlu, ikinci parmak sırtında hiperkeratotik kurutlu lezyon saptandı, sol ayak plantar bölgede kallus dışında patoloji saptanmadı (Resim 1). Hastanın ilk başvurusu sırasında yapılan laboratuvar tetkiklerinde lökosit: 10500/mm³ (\%70 PNL), CRP: 5,3 mg/dl ( $\mathrm{n} \leq 0,5 \mathrm{mg} / \mathrm{dl}$ ), sedimantasyon: $92 \mathrm{~mm} /$ saat, HbA1c \%8,2 olarak belirlendi. Ayak direkt grafisinde sağ ayak üçüncü parmakta osteomiyelit saptandı. Arteriyel doppler ultrasonografisinde her iki tarafta crural arterlerde stenooklüzif değişiklikler ve deri altı dokuda ödem saptandı; venöz doppler incelemede ise derin ven trombozu izlenmedi. Ampirik ampisilin/sulbaktam tedavisi başlanan hastanın doku kültüründe Achromobacter xylosoxidans (amikasin ve gentamisin dirençli, siprofloksasin ve sefepim orta duyarlı, seftazidim ve piperasilin/tazobaktam duyarlı) (VI-TEC 2 otomatize sistem bioMérieuxInc, MercyL'etoil, Fransa) üremesi saptandığı için hastaya seftazidim 3 gram/ gün tedavisi başlandı. Yatışından üç hafta sonra hastanın nekroz içeren enfekte ayak parmağı Ortopedi Kliniği tarafından ampute edildi. Takiplerinde doku kültüründe üremesi devam etmesi ve akıntı şikayetinin eklenmesi nedeniyle debritman cerrahisi uygulandı. Hastanın toplam seftazidim tedavisi iki aya tamamlandı. Hastanın kontrol doku kültüründe üreme olmadı. Diyabetik ayak konseyine kontrole gelmesi önerilerek taburcu edildi.

\section{Olgu 2}

Otuz yıldır diyabet tanısıyla izlenen, bir yıl önce koroner arter by-pass operasyonu yapılan 53 yaşındaki erkek hastanın operasyondan bir ay sonra sağ ayak başparmağında akıntılı kötü kokulu yara gelişmiştir. Hastanın özgeçmişinde on üç yıldır insülin kullandığı ve dört yıldır kronik böbrek yetmezliği nedeniyle hemodiyaliz tedavisi uygulandığı öğrenilmiştir. Başvurduğu hekim tarafından amoksisilin/ klavulonat ve hiperbarik oksijen tedavisi başlanan hasta, şikayetlerinin gerilememesi üzerine hastanemiz diyabetik ayak konseyinde değerlendirilerek Enfeksiyon Hastalıkları Kliniği'ne yatırılmıştır. Fizik muayenesinde polio sekeli olan hastanın sol ayaktaki mevcut yarası Wagner 3 ve Pedis 2 olarak değerlendirildi. Hastaya ortopedi hekimleri tarafından yara debritmanı ve sağ ayak başparmak amputasyonu yapıldı. Operasyon sonrası şikayeti olmayan hasta diyabetik ayak konseyine on beş gün ara ile kontrole çağrılarak taburcu edildi. Düzenli kontrollere gelmeyen hastanın operasyon sonrası 2. ayda yapılan fizik muayenesinde ampüte parmak çevresi ve ikinci parmakta eritematöz ödem ve maserasyon, süturlarda ayrılma ve hemorajik akıntı, sütur hattı çevresinde nekroz saptandı (Resim 2). Hastanın insülin tedavisini düzenli almadığı ve kan şekeri regülasyonunun iyi olmadığı görüldü. Doku kültürü alınarak tekrar Enfeksiyon Hastalıkları Kliniği'ne yatırıldı. Laboratuvar incelemelerinde, lökosit: 9250/mm³, CRP: 3,9 mg/dl, sedimantasyon: $79 \mathrm{~mm} / \mathrm{saat}$ saptandı. Doku kültüründe Achromobacter xylosoxidans (amikasin ve gentamisin dirençli, siprofloksasin ve sefepim orta duyarlı, seftazidim ve piperasilin/tazobaktam duyarlı) (VI-TEC 2 otomatize sistem bioMérieuxInc, MercyL'etoil, Fransa) üremesi saptanması üzerine piperasilin/tazobaktam 2,25 gr flakon $3 \times 1$ IV ve eş zamanlı hiperbarik oksijen tedavisi başlandı. Hastanın direk grafilerinde amputasyon yerinde osteomyelit

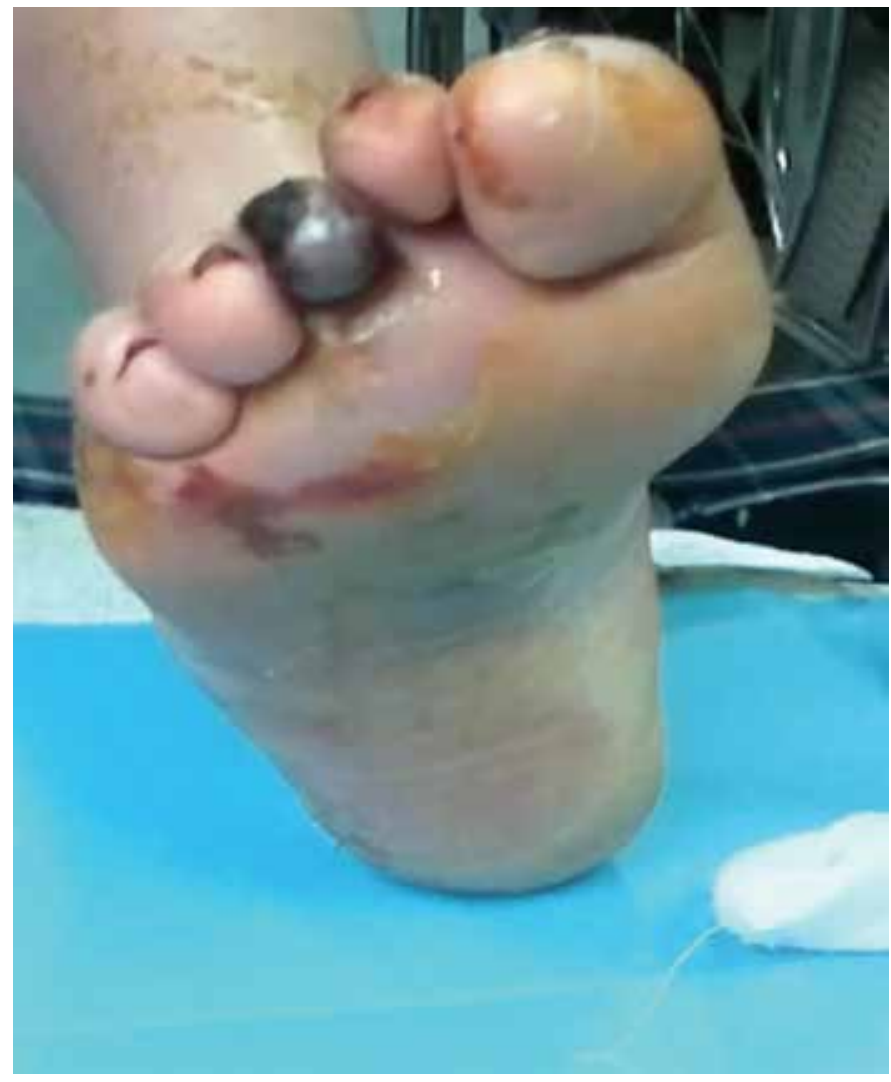

Resim 1. Sağ ayak üçüncü parmak uç kısımda nekrotik enfekte görünüm 
saptandı. Yaklaşık on yedi gün boyunca antibiyotik tedavisi almasına rağmen hastanın akıntısında azalma olmaması, yara yerinde kapanmanın gecikmesi üzerine tekrar doku kültürü alındı. Doku kültüründe Achromobacter xylosoxidans ve Corynebacterium striatum üremesi oldu. Hastanın operasyon yerinde nekroz gelişmesi nedeniyle tekrar cerrahi girişim uygulandı. Yara debritmanı ve ikinci parmak ampütasyonu yapıldı. Hastanın parenteral antibiyotik tedavisi 45 güne tamamlanarak taburcu edildi. Hasta iki hafta arayla diyabetik ayak konseyinde değerlendirildi. Yaranın iyileşmekte olduğu, yara boyutlarının küçüldüğü ve operasyon yerinin sorunsuz olduğu görüldü.

\section{Tartışma}

Küresel bir sağlık sorunu olan diyabet, önemli bir mortalite ve morbidite nedenidir. 2003 yılında 194 milyon diyabet olgusu tahmin edilirken, 2025 yllında daha uzun yaşam beklentisi ve değişen beslenme alışkanlıkları nedeni ile bu sayının 380 milyona yükseleceği düşünülmektedir (3). Diyabetik hastaların pek çok enfeksiyon hastalıklarına eğilimi artmıştır. Ancak ayak enfeksiyonları tüm diyabet komplikasyonları içinde hastaneye en sık başvuru ve en uzun süre yatma nedenidir (5).

Diyabetik ayak enfeksiyonları, periferik nöropati ve doku perfüzyonunun yetersizliği sonucunda oluşur. Uygun tedavi edilmediğinde daha derin dokulara ilerleyerek doku veya ekstremite kaybına neden olabilir. Tanı ve tedavisi zor olan diyabetik ayak enfeksiyonlarında multidisipliner yaklaşım gereklidir $(6,7)$. Ortopedi, enfeksiyon hastalıkları, endokrinoloji, dermatoloji, kalp damar cerrahisi ve

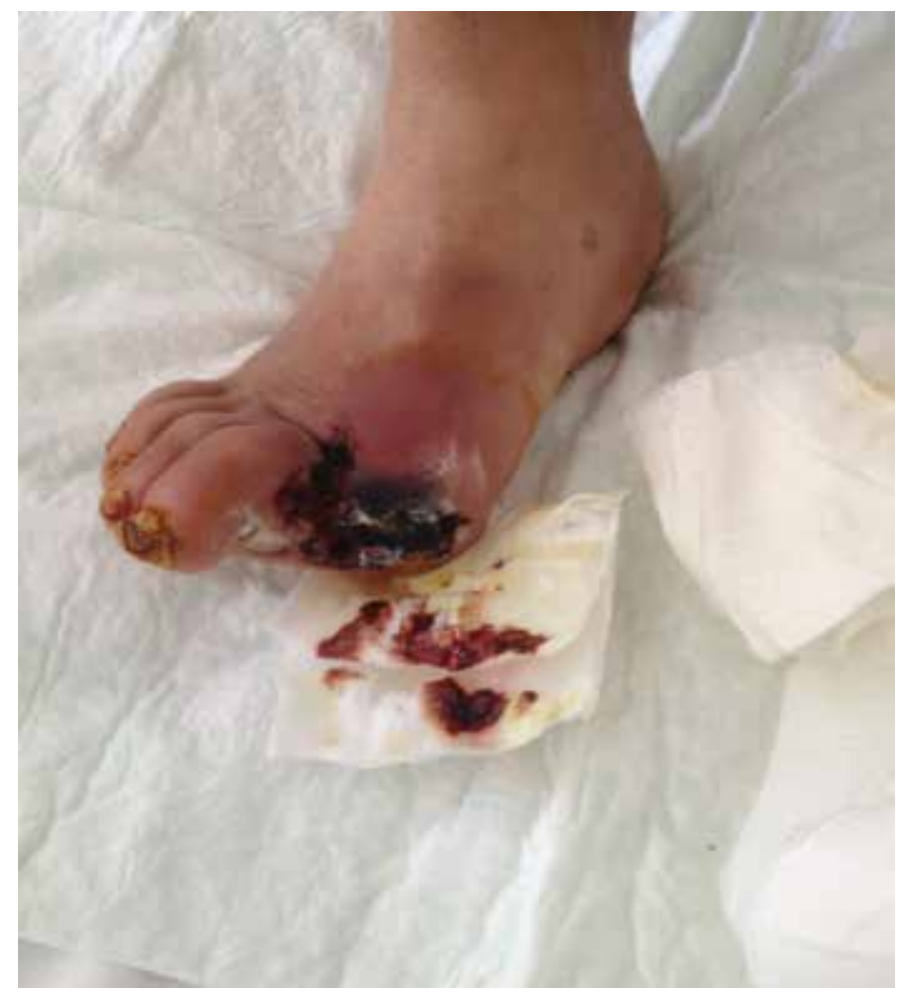

Resim 2. Ampüte ve ikinci parmakta eritematöz ödem ve maserasyon, süturlarda ayrılma, hemorajik akıntı, sütur çevresinde nekroz plastik cerrahi hekimlerinden oluşan ekip tarafından hasta değerlendirilmeli ve tedavisi planlanmalıdır. Uygun antibiyotik tedavisinin yanı sıra cerrahi drenaj, debritman ve ölü dokuların rezeksiyonu yapılmalı, uygun yara bakımı uygulanmalı ve metabolik bozukluklar düzeltilmelidir.

Diyabetik ayak ülserlerinde tanı genellikle klinik olarak konulmaktadır. Mikrobiyolojik tanı, tedavinin doğru yapılması açısından çok önemlidir. Mikrobiyolojik tanı açısından yüzeyel sürüntü kültürlerinin değeri düşüktür. Derin doku kültürü veya kemik kazıntı kültürleri alınmalıdır (7). Olgularımızdan alınan doku kültürlerinde Achromobacter xylosoxidans saptanmıştır.

Achromobacter xylosoxidans ilk defa 1971 yılında Yabuuchi ve Ohyama tarafından kronik otitis media olan hastaların pürülan kulak akıntılarında tanımlanmıştır. Achromobacter xylosoxidans glukozu fermente etmez. Oksidaz ve katalaz pozitif olup doğal çevrede yaygın olarak bulunur. Çevre koşullarına dirençlidir ve tipik olarak nemli ortamlarda yaşar (8). Serum fizyolojik, diyaliz solüsyonları, intravenöz ve kontakt lens sıvıları, klorheksidin glukonat solüsyonları ve ultrason jeli gibi sağlık bakım setlerindeki sulu çözeltilerde yaygın olarak kolonize olabilmektedir. Ayrıca mekanik ventilatör setleri, neonatal inkübatörler, intravenöz kateterler, üriner kateterlerden de izole edilmiştir (9). Achromobacter xylosoxidans en sık malinite, kalp hastalıkları, diabetes mellitus, kronik böbrek yetmezliği, kronik obstrüktif akciğer hastalığı, HIV enfeksiyonu, kistik fibroz gibi eşlik eden komorbid sağlık sorunu olan ve/veya kalıcı tıbbi cihazlara bağlı olan kişilerde enfeksiyona neden olmaktadır. Genellikle düşük virülanslı olarak kabul edilmesine karşın bağışıklık sistemi baskılanmış hastalarda yüksek morbidite ve mortaliteye neden olabilmektedir.Temelde komplike olmayan bakteriyemi Achromobacter xylosoxidans enfeksiyonunun en sık görülen formu olsa da bu organizma enfeksiyonlarının geniş bir klinik çeşitliliği vardır. Achromobacter xylosoxidans kulak ve göz enfeksiyonları, idrar yolu enfeksiyonları, karın içi enfeksiyonları, karaciğer apseleri, yumuşak doku enfeksiyonları, osteomyelit, protez enfeksiyonları, menenjit, ventrikülit, endokardit ve pnömonide etken olarak tespit edilmiştir $(4,9)$. Diyabetik ayak enfeksiyonu etkeni olarak ulaşılabildiği kadarıyla literatürde bildirilen başka olguya rastlanmamıştır.

Diyabetik ayak enfeksiyonları tıbbi açıdan acil enfeksiyonlardır. Başlangıç antibiyotik tedavisi genellikle ampirik olarak başlanmakta, sonrasında kültür sonuçlarıyla modifikasyon yapılmaktadır. Tek başına antibiyotik tedavisi yeterli olmayan olgularda mutlaka cerrahi girişim uygulanmalıdır. Olgularımıza kültür sonuçlarına göre antibiyotik tedavisi başlanmış ve cerrahi girişim uygulanmıştır.

Achromobacter xylosoxidans tüm aminoglikozidlere karakteristik olarak dirençlidir ve rifampin, trimetoprimsulfametoksazol, siprofloksasin ve diğer kinolonlara ise değişen oranlarda direnç gösterir (9). Minosiklin, imipenem, meropenem, piperasilin ve piperasilin-tazobaktam Achromobacter xylosoxidans'a karşı yüksek oranda etkilidir (8). Olgularımızın birine antibiyotik duyarlılık sonuçlarına göre seftazidim, diğerine piperasilin/tazobaktam tedavisi verildi. İki olguda da parmak ampütasyonu yapılmış, ancak ikisinde de tekrar cerrahi debritman uygulanması gerekli 
olmuştur. Bu duruma hastaların kan şekeri regülasyonlarının ve kan dolaşımlarının yeterli olmaması neden olabileceği gibi Achromobacter xylosoxidans'ın zor tedavi edilmesi de neden olmuş olabilir.

\section{Sonuç}

Diyabetik ayak hastalarında önemli bir morbidite ve mortalite nedeni olan ayak enfeksiyonlarının tedavisi acil bir durumdur. Hastanın multidisipliner bir şekilde değerlendirilmesi, ülserasyonun ve enfeksiyonun sınıflandırılması gerekir. Hastaların etkili bir biçimde tedavisi için akut ve kronik enfeksiyonlarda olası patojenlerin ve antibiyotik duyarlııklarının bilinmesi önemlidir. Diyabetik ayak enfeksiyonunun mikrobiyolojik tanısında doku kültürü yapılması gerçek etkeni saptamak açısından çok önemlidir. Mikrobiyolojik örneklemin doğru yapılması bizim olgularımızda olduğu gibi nadir görülen etkenlerin saptanması ve tedavisi açısından yol göstericidir.

\section{Kaynaklar}

1. Chand G, Mishra AK, Kumar S, Agarwal A. Diabetic foot. Clinical Queries: Nephrology 2012;1:144-50.

2. Roberts AD, Simon GL. Diabetic foot infections: the role of microbiology and antibiotic treatment. Semin Vasc Surg 2012;25:75-81.

3. Dizbay M. Diyabetik ayak infeksiyonları. Ankem Derg 2010;24:144-9.

4. Dirican A, Arda B, TaşbakanMI, ve ark. Nötropenik Ateş Olgusunda Nadir Bir Bakteremi Etkeni: Achromobacter xylosoxidans Flora 2007;12:108-10.

5. Baktıroğlu S. Diyabetik ayak infeksiyonları: genel bilgiler ve cerrahi tedavi. Ankem Derg 2012;26:204-11.

6. Paisley $A N$, Kalavalapalli $S$, Subudhi $C P$, et al. Real time presence of a microbiologist in a multidisciplinary diabetes foot clinic. Diabetes Res Clin Pract 2012;96:1-3.

7. Ulusoy S, Arda B, Bayraktar F, ve ark. Diyabetik Ayak Infeksiyonları: 179 Olgunun Değerlendirilmesi. Flora 2000;5:220-8

8. Tokuyasu H, Fukushima T, Nakazaki H, Shimizu E. Infective endocarditis caused by Achromobacter xylosoxidans: a case report and review of the literature. Intern Med 2012;51:1133-8.

9. Claassen SL, Reese JM, Mysliwiec V, Mahlen SD. Achromobacter xylosoxidans infection presenting as a pulmonary nodule mimicking cancer. J Clin Microbiol 2011;49:2751-4. 